\title{
Investigation of the Current Energy Sector in Jordan: Energy Strategy, Resources and Regulatory Framework
}

\author{
Ahmed Al-Salaymeh*, Heba AlZaben, and Nadeen Habash \\ Mechanical Engineering Department, Faculty of Engineering \& Technology, University of Jordan, Amman \\ 11924, Jordan
}

\begin{abstract}
Due to the increase in demand for energy resources and the effect of the ongoing events in the region of Jordan. The energy resources are decreasing over time and that also has a negative effect on the Jordanian economy. Providing energy is always a vital and significant problem in Jordan. Jordan on the other hand is a rich in some of the renewable energy resources, which are not fully used until this moment. Therefore, it is essential to find alternative and renewable energy resources. Moreover, there is also a lack in creating a clear and long term future plans in the energy field. In this paper, energy sources and the efficiency of the energy sector in Jordan will be specified, in addition to the determination of the cofounders and sponsors for enhancing and developing the energy sector. The shift in policy that is needed to increase this efficiency will be also investigated.
\end{abstract}

Keywords: Energy resources. Renewable energy. Energy sector. Energy policy.

\section{Introduction}

Electric energy is a vital factor for the growth of civilization, and to sustain a life on earth. There are many sources that can be used to generate electricity such as fuel and natural gas. However, due to the shortage of these resources, there is a need to find other alternatives. Most of the electric energy in Jordan is produced by natural gas and fossil fuel that is imported from the neighbouring Arab countries. These resources have many disadvantages such as high running cost, and pollution in addition to the increasing of the oil price (Fig1) that is imported from Egypt and also the shortage of the supply amount from Iraq due to the unstable political issues there.

The demand on electrical energy is increasing steadily due to the population growth (Fig2).

\footnotetext{
${ }^{*}$ Corresponding author

E-mail: salaymeh@ju.edu.jo

(C) 2016 International Association for Sharing Knowledge and Sustainability

DOI: $10.5383 /$ ijtee.12.02.002
}

Due to these reasons, other types of energy resources are needed to be investigated. In addition, renewable energy resources and the efficiency of the energy sector in Jordan will be also studied in this paper.

Investigating of renewable energy sources in Jordan has been studied only in few papers. The demand on the energy on the other hand is increasing steadily, and therefore there is a need to investigate other sources of energy. As it found in the literature, most of the surveys were carried out in order to investigate the household energy consumption in Jordan. For instance, a survey about the energy demand and consumers was carried out and used to help the energy decision makers [4]. AlDabbas on the other hand [5], also studied the energy resources in Jordan and the household energy consumption. This paper will focus more on the renewable energy sources as an alternative for the fuel and natural gas. 


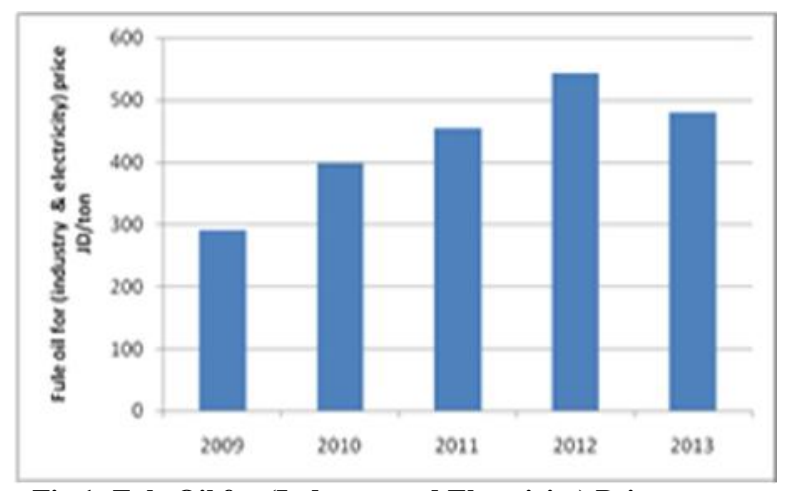

Fig.1: Fule Oil for (Industry and Electricity) Prices

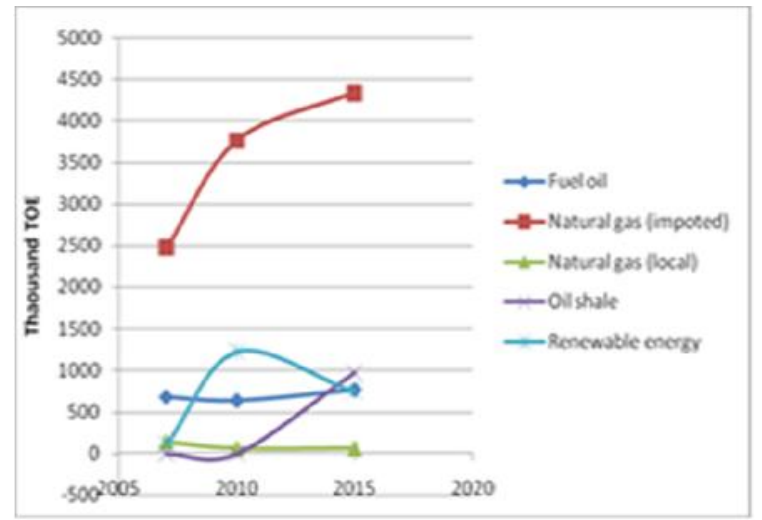

Fig.2: Primary Energy Demand (2007-2020) in Ton Oil Equivalent

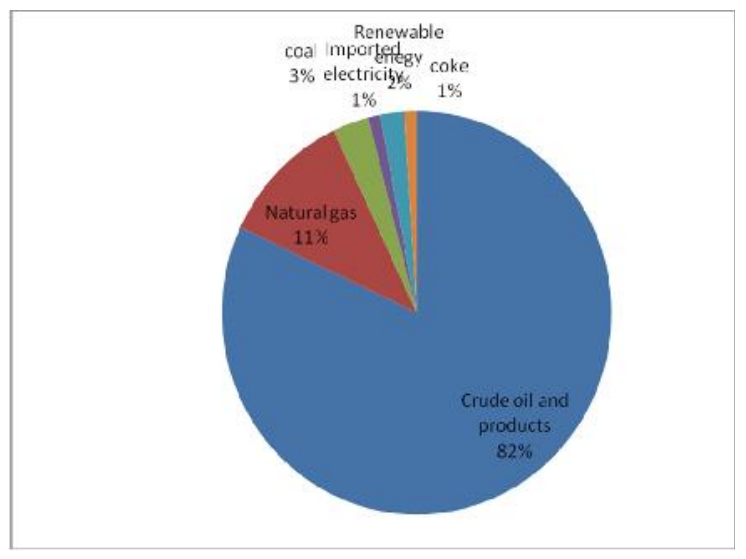

Fig.3: Primary Energy Consumption 2013

\section{Energy Sources in Jordan}

The demand on the primary energy sources in Jordan has been growing at an average annual rate of $4 \%$ over the past ten years. It is expected to continue in growing at an average annual rate of $3 \%$ during the next decade. However, the demand on electrical energy is growing much faster.

The Risha gas field which was discovered in 1987 is currently the only source of hydrocarbon fuel in Jordan.
The produced gas is currently used for electricity generation, and it represents $11 \%$ of the total electricity produced in Jordan. Oil exploration on the other hand is taking place in Jordan with marginal results so far. Jordan has also enormous resources of oil shale deposits, and blessed with high potential of solar and wind energy resources.

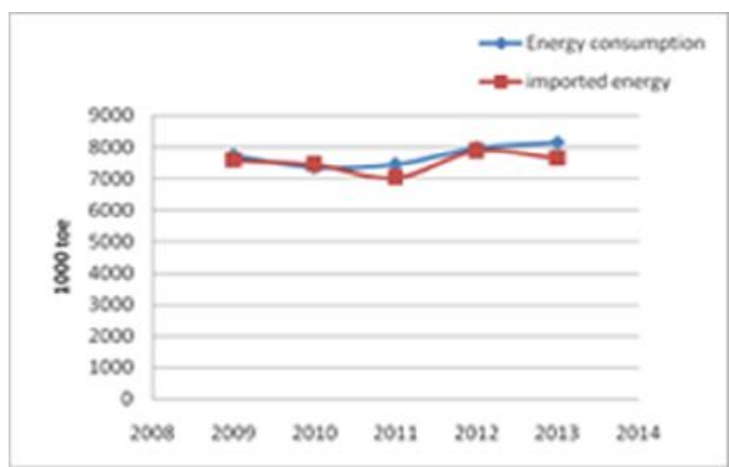

Fig.4: Energy Consumption and Imported Energy

\section{Renewable Energy Sources in Jordan}

Jordan started its activities in renewable energy back in the late 1970's. The government of Jordan established the National Energy Research Center (NERC) in 1998 to coordinate all research and development activities related to renewable energy and energy conservation in the country.

Jordan is a rich country with many natural resources such as solar, wind, geothermal and bio fuel. These resources are clean and have no bad effects on the environment. Jordan lies in the earth-sun belt area and has a high potential of solar energy. The annual average of global solar energy is approximately 1800

$\mathrm{kWh} / \mathrm{m}^{2} /$ year, where the annual average solar irradiance on a horizontal surface has a range between $5-7 \mathrm{kWh} / \mathrm{m}^{2}$ [7]. Solar energy is mainly used in Jordan for domestic solar water heating. More than 25 manufacturers are producing a locally designed solar water heaters systems. In addition, 100 photovoltaic systems are used in remote areas throughout the country. These systems cover different applications such as water pumping, telecommunications, schools and others.

Jordan has rich wind energy resources. The Jordan Wind Atlas indicates that some areas in the Northern and Western regions of the country have wind speeds that exceed $7 \mathrm{~m} / \mathrm{s}$ [7]. This speed has a big impact in producing electrical power.

There are two operating wind farms in Jordan, one with a capacity of $320 \mathrm{~kW}$, established in 1988 in cooperation with a Danish firm and considered as a pilot project. The 
other most recent one has a capacity of $1.2 \mathrm{MW}$, established in 1996 in cooperation with the German Government under a program called ELDORADO. Both wind farms are fully operated. Wind Energy is also used for water pumping in Jordan, using a locally manufactured mechanical windmill.

Jordan, which is considered as part of the Ring of Fire, is tectonically active and could be considered as potential region for generation of geothermal energy from the available resources. Jordan encounters geothermal energy resources in two main forms, medium and low energy with variation of temperature ranges from 110 $114{ }^{\circ} \mathrm{C}$ and $30-65{ }^{\circ} \mathrm{C}$ respectively. Many houses in Jordan use the shallow geothermal for heating purposes.

There are many projects in Jordan that use the biomass energy for production of electricity since it is clean and renewable energy, such as Russaifa Biogas Plant with a capacity of 3.5 MW and Samra Biogas plant with a capacity of $6 \mathrm{MW}$. In addition to the domestic projects such as Al Khaldieh which is a small animal farm that produces $3.5 \mathrm{KW}$. The animal waste contributes of $42 \%$ of the total potential, and it is concentrated in three important regions in Jordan; Mafraq, Zarqa, and Irbid. It can produce more than half million cubic meter of biogas.

\section{The Efficiency of Renewable Energy in Jordan}

The overall strategy for energy sector in Jordan aims at diversification of energy sources and reduction of reliance energy imports stated that the renewable energy contributes with (7\%) of an overall energy mix by 2015 and $(10 \%)$ by 2020 . To achieve these values many projects were suggested and studied some of these projects still under studying. Some projects were discussed in before 2009 and still not installed and under studying resulting in just $2 \%$ by 2013 of renewable energy sharing in energy sector which is too low compared to $7 \%$ by 2015 . The ministry of energy and mineral resources put laws that encourage private sectors to share in developing renewable energy sector and many projects were received from that date and still waiting to be approved and implemented. There is a slow growth in the sector although of the efficient projects that approved and still under studying and waiting to be implemented. The process of installing some projects starting from the tenders to installation and running took more than 3 years which is long period so energy sector has to put lows to speed up this process.

\section{General Statistics about Energy Sector in Jordan}

Jordan is considered as low-middle income country, with an approximate average income of 448 JD per month in 2012, and a population of 6.388 million inhabitants [6]. It suffers from natural resources including water, crude oil and other commercial minerals. Thus, Jordan depends heavily on imports of crude oil, and natural gas from neighbouring Arab countries as the main sources of energy. The population growth rate showed a significant decrease during the period 1994-2004 and recorded $2.6 \%$, and decreased to $2.2 \%$ during the period $2004-$ 2013 [6].

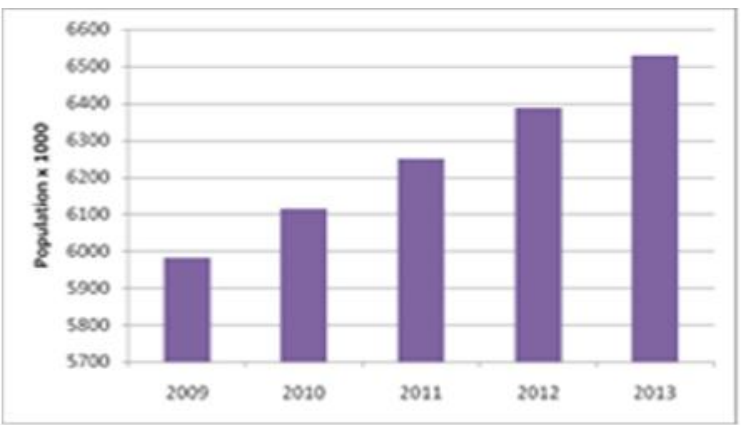

Fig.5: Population Growth in Jordan

In accordance with the Renewable Energy and Energy Efficiency Law provisions, the Government of Jordan has searched for qualified investors that are interested in investment in renewable energy projects for power generation. Thirty four of the received applications have been shortlisted with total capacity of (1000 MW), those successful applicants received a Memorandum of Understanding from the Government which enables them to proceed with preparing their proposals for their proposed projects.

The Renewable Energy and Energy Efficiency Fund has been established, that provides a good financial framework to support energy efficiency programs. This includes awareness campaigns and training in all sectors, as well as renewable energy projects. The resources of the Fund are annual budget allocations, investment revenues and foreign donation.

The Ministry of energy has proceeded to carry out the projects for the construction of oil terminal to include oil tanks with a capacity of 100 thousand ton at Aqaba. Also the Ministry has started taking the necessary actions to diversify the sources of imported natural gas by importing liquefied natural gas through the Aqaba port.

\section{The Role of Different Organizations in Developing the Energy Sector in Jordan}

Over the last decade, the energy sector of Jordan has been undergoing significant development with the Government's program for economic reform. In which the private sector is expected to play a leading role. The Government's energy policy aims to improve the efficiency of operations and development of the energy sector to meet the energy needs of the country in an economic, and environmentally sustainable manner. In 
addition to develop the local energy resources including renewable energy to reduce the imported energy cost.

The energy sector is currently supervised by the Ministry of Energy and Mineral Resources (MEMR), which is responsible for policy and strategy formulation, regulation of oil and gas, contracting of private independent power developments, and imports of energy. The Electricity Regulatory Commission (ERC) has the responsibility for electricity sector regulation as established under the Electricity Law. The other key Ministries involved in the sector are - Ministry of Planning (MoP), Ministry of Finance (MoF), and the Executive Privatization Commission (EPC), which is responsible for privatization. MEMR creates the laws providing for the abolition customs duties and sales tax is decreased for everything related to renewable energy to encourage investment in this sector but this is not enough, a new Stringent legislation must be applied for the Construction sector and to build green building that saves energy. Factories also must share this responsibility in saving energy as they are the second in electrical consumption after household with $24 \%$. Laws must be created to force them to generate electricity using renewable energy such as using photovoltaic cells to generate part of the electrical power needed to run the factories. This will save energy and cost, and also specify areas that have potential renewable energy sources to build industrial areas there including green factories that save power and also have less effect on environment. Most population do not recognise the problem of energy and the importance of renewable energy. Therefore creating a conscious generation about renewable energy and its importance will guide and direct the ideas of the future Economists businessmen and man power towards developing this sector rapidly and efficiently inside Jordan with less reliance on outside investors; this can be done by covering this subject in wider range in school curriculums.

\section{Different Challenges That Faces the Energy Sector in Jordan}

There are major challenges that Jordan is experiencing in the energy sector such as the different difficulties expanding the crude oil refinery due to the Jordan Petroleum Refinery Company's inability to attract a strategic partner. In addition to the limited electricity generation capacity, difficulties securing the necessary investments to meet growing demand for electricity that is increasing due to human growth in addition to refuges from neighbour countries 650,000 refugees from Syria (not all in camps). In addition to the limited quantity of natural gas available for import from Egypt. High cost of renewable energy projects/systems for electricity generation, Regulatory legislation issues including lack of legislation for renewable energy projects covering facilities, customs exemptions and necessary tax. Need for updating and restructuring current Natural Resources
Authority (NRA) legislation, risk of oil shale investor companies not succeeding in developing the necessary technologies.

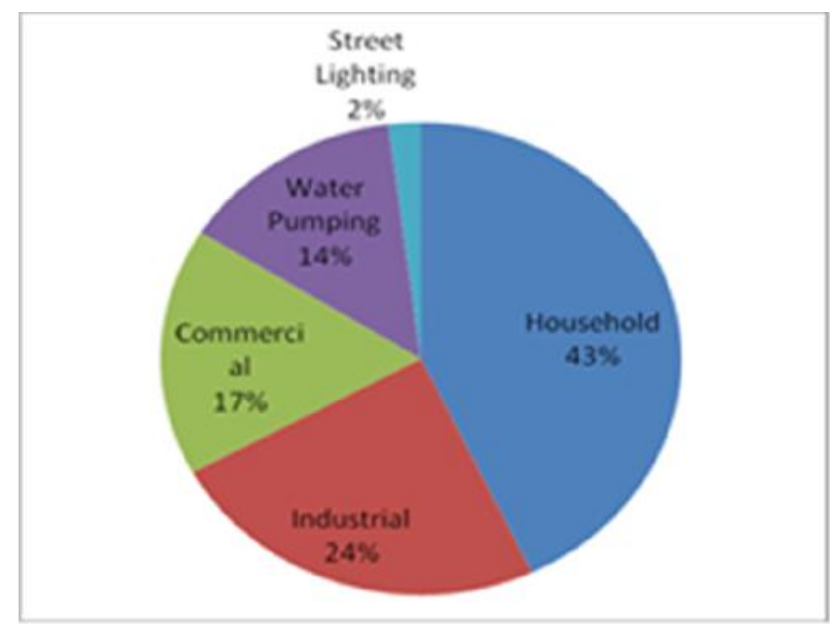

Fig.6: Electrical Energy Consumption (2013)

The Government of Jordan faces different challenges in the energy sector, due to population growth, increased per capita consumption of energy and a reduction in the availability of fuel. Jordan imports 96 percent of its oil and gas.

The rising cost of importing energy resources has forced the government to reconsider its energy consumption policies and address the issue of reliance on international energy markets for direct imports.

The energy sector is one of the strongest prospects for investment in the Jordanian economy. Although challenges remain, most notably securing financing during the downturn and keeping up with the pace of demand, the sector should see major growth in the next two decades.

\section{Suggested Solutions to Develop the Energy Sector in Jordan}

the development of the energy sector in Jordan should be very important for people, companies and different organizations through working on several energy initiatives and investment projects, also putting a regulations and introducing innovative incentive schemes in order to mitigate the risks that these challenges present, and as a proper enabling environment for positive growth of the sector.

\section{Conclusions}

This paper has identified the energy sector in Jordan from many points, such as the available natural resources (renewable energy), the organizations that help the ministry of energy and mineral resources to enhance and 
to draw different strategies to find new projects to develop the energy sector in Jordan. In addition, different challenges that face the energy sector was discussed and suggested solutions were proposed to solve the different challenges.

\section{References}

[1] Annual Report on Environmental Statistics, 2002, Department of Statistics, Amman, Jordan

[2] "Jordan Agenda 21" Towards Sustainable Development, UNDP, Jordan , 2000
[3] Annul Reports,2009-2013, Ministry of Energy and Mineral Resources, Amman, Jordan NERC (National Energy Research Center) web site.

[4] Aburas, R., \& Fromme, J. W. (1991). Household energy demand in Jordan. Energy policy, 19(6), 589-595.

[5] Al-Dabbas, M. A. THE DECEMBER 2010 HOUSEHOLD ENERGY SURVEY IN JORDAN. Journal of Engineering Sciences, Assiut University, Vol. 40, No. 3, pp.764- 745, May 2012.

[6] Department of Statistics (DoS). Statistical yearbook 2013. Amman, Jordan.

[7]U.S. Department of Commerce -2015, http://www.export.gov/eac.. 